\title{
Upaya Meningkatkan Minat Belajar Matematika Melalui Media Pembelajaran Berbantuan Komputer
}

\author{
Yuliar Astuti Dewi \\ SMA Negeri 8 Bandar Lampung \\ Corresponding Author. E-mail: yuliadewi63@ymail.com
}

\begin{abstract}
Abstrak
Penelitian ini bertujuan untuk meningkatkan minat belajar matematika dan mendeskripsikan proses pembelajaran matematika melalui media pembelajaran komputer dengan program MS Power Point. Metode penelitian yang digunakan adalah metode eksperimen semu yaitu penelitian tindakan kelas dengan menggunakan prosedur PAOR. Hasil penelitian menunjukan bahwa berdasarkan data yang ditunjukkan dengan hasil angket, wawancara ataupun observasi selama proses pembelajaran berlangsung, hasil rata-rata angket minat belajar sebelum tindakan adalah 62,17\%, setelah siklus I adalah 69,70\% dan setelah siklus II adalah 76,88\% (tinggi) berarti ada kenaikan minat belajar dari pra penelitian ke siklus I 7,53\% dan dari siklus I ke siklus II sebesar 7,18\%. Untuk rata rata hasil observasi minat belajar pra penelitian adalah $38,44 \%$ pada siklus I adalah 52,40\% dan siklus II adalah 70,11\% Dari pra penelitian ke siklus I ada kenaikan sebesar $13,96 \%$, dari siklus I ke siklus II naik 17,71\%. Secara keseluruhan dari pra penelitian sampai akhir penelitian ada kenaikan 31,67\%. Hal tersebut menunjukan bahwa dengan menggunakan media pembelajaran berbantuan komputer program MS Power Point siswa menjadi lebih bersemangat untuk belajar matematika.
\end{abstract}

Kata kunci: Media Pembelajaran, Minat Belajar, Power Point

\begin{abstract}
This study aims to increase interest in learning mathematics and describe the process of learning mathematics through computer learning media with the MS Power Point program. The research method used is a quasi-experimental method of classroom action research using the PAOR procedure. The results showed that based on the data shown by the results of the questionnaire, interview or observation during the learning process took place, the average results of the questionnaire interest in learning before the action was $62.17 \%$, after the first cycle was $69.70 \%$ and after the second cycle was 76, 88\% (high) means there is an increase in interest in learning from prestudy to the first cycle of $7.53 \%$ and from the first cycle to the second cycle of $7.18 \%$. For the average results of observations of pre-research learning interest is $38.44 \%$ in the first cycle is $52.40 \%$ and the second cycle is $70.11 \%$ From pre-research to the first cycle there was an increase of 13.96\%, from the first cycle to the second cycle up $17.71 \%$. Overall from the pre-study to the end of the study there was an increase of $31.67 \%$. This shows that by using computer-assisted learning media MS Power Point program students become more eager to learn mathematics.
\end{abstract}

Keywords: Learning Media, Learning Interest, Power Point

\section{PENDAHULUAN}

Pada jaman kemajuan teknologi ini sebagian besar perilaku manusia dipengaruhi oleh pesatnya perkembangan dan kecanggihan teknologi. Teknologi dibuat untuk membantu manusia dalam kehidupannya, termasuk dalam bidang pendidikan. Guru harus bisa menerapkan kecanggihan teknologi dalam kegiatan belajar dan mengajarnya untuk mempermudah proses pembelajaran. Seorang guru yang mengajar di depan kelas dengan metode mengajar dan media pembelajaran yang 
kurang inovatif membuat suasana kelas menjadi monoton. Kondisi ini membuat siswa kurang bergairah dalam belajar. Perlu adanya peningkatan mutu kinerja yang professional demi terciptanya peserta didik yang utuh.

Matematika sebagai salah satu bidang ilmu yang diberikan di sekolah merupakan mata pelajaran yang dianggap "sulit". Banyak rumus-rumus yang harus dipelajari dan dihafal. Apabila guru dalam memberikan pembelajaran tidak secara inovatif maka banyak pula siswa yang merasa kesulitan. Dalam hal ini diperlukan metode-metode pembelajaran atau media pembelajaran yang menyenangkan dan tidak membosankan. Selama ini masih sering dijumpai guru yang mengajar dengan cara yang sederhana di depan kelas tanpa menggunakan media yang baik kecuali hanya sebuah papan tulis, kapur dan buku pegangan. Sehingga banyak siswa menganggap bahwa matematika adalah pelajaran yang sulit dan mereka merasa bahwa media pembelajaran yang diberikan guru selama ini sangat membosankan dan kurang menarik perhatian siswa.

Siswa merasa jenuh sehingga pelajaran matematika merupakan pelajaran yang tidak digemari. Padahal jika matematika diberikan secara inovatif dan menyenangkan maka diharapkan siswa akan lebih tertarik untuk mempelajarinya. Di kelas siswa akan bergairah untuk menyimak apa yang akan disampaikan oleh gurunya. Dari hari ke hari model pembelajaran secara sederhana itu selalu dilakukan terus menerus tanpa adanya perubahan. Guru harus banyak melakukan langkahlangkah konkrit dengan banyak membaca referensi, penataran, penggunaan model pembelajaran yang relevan dan penggunaan media pembelajaran yang yang baik. Salah satu langkah inovatif dalam pembelajaran di kelas yang bisa digunakan adalah dengan penggunaan media pembelajaran berbantuan komputer dengan program MS Power Point.

Berdasarkan penelitian yang telah dilakukan sebelumnya, upaya dalam meningkatkan minat belajar matematika siswa telah banyak di teliti (Fitri \& Wardi, 2026; Harsyad, Afif, \& Abrar, 2016; Oktaria, Zulkardi, \& Somakim, 2013; Siagian, R.E.F., 2015; Suratno, 2013; Wibowo, 2017) Serta pengembangan media pembelajaran berbantuan power point pun telah banyak dilakukan (Afandi, 2017; Ghofuri, Sanusi, \& Krisdiana, 2014; Ginting \& Hermansyah, 2012; Wahidi, 2017). Namun, belum adanya penelitian yang mengupayakan untuk meningkatkan minat belajar matematika melalui pembelajaran berbantuan MS Power Point

Berdasarkan penelitian terdahulu keterbaruan penelitian ini terletak pada digunakannya media pembelajaran berbantuan program MS Power point sebagai upaya untuk meningkatkan minat belajar matematika siswa. Maka, tujuan penelitian ini adalah untuk meningkatkan minat belajar matematika dan mendeskripsikan proses pembelajaran matematika melalui media pembelajaran komputer dengan program MS Power Point

\section{METODE PENELITIAN}

Metode penelitian yang digunakan adalah metode eksperimen semu yaitu PTK (Penelitian Tindakan Kelas). Penelitian ini menggunakan prosedur PAOR, yaitu Planing, Action, Observasi atau pengamatan, dan Refleksi atau evaluasi. Dalam prosedur ini akan digunakan minimal dua siklus yaitu: Siklus I yang terdiri dari rencana tindakan, Observasi, Angket, Wawancara dan Refleksi, Siklus II terdiri dari Persiapan Tindakan. Persiapan yang dilakukan pada siklus II pada dasarnya 
Desimal, 2 (3), 2019 - 213

Yuliar Astuti Dewi

sama seperti pada rencana tindakan pada siklus I, hanya ditambah dengan perbaikan-perbaikan apabila pada siklus I ditemukan kekurangan.

Data diperoleh dari hasil observasi, angket dan hasil wawancara. Indikator keberhasilan dalam penelitian ini adalah meningkatnya minat belajar matematika yang dapat dilihat pada rata-rata hasil observasi dan hasil angket pada pra penelitian dan pada akhir penelitian yang telah diberikan kepada siswa, serta adanya respon positif dari siswa pada setiap kegiatan pembelajaran. Perhitungan presentase setiap indikator dapat dihitung dengan rumus: $\frac{\text { Jumlah skor seluruh siswa }}{\text { Jumlah siswa } x \text { skor maksimal }} \times 100 \%$

\section{HASIL DAN PEMBAHASAN}

Penelitian tindakan kelas ini sebagai upaya meningkatkan minat belajar matematika dengan pelaksanaan kegiatan belajar mengajar menggunakan media pembelajaran berbantuan komputer dengan program MS Power Point. Obyek dari penelitian ini adalah siswa kelas X SMA berjumlah 32 orang. Hasil angket respon siswa sebelum guru menjelaskan dengan bantuan komputer program MS Power Point ditampilkan pada Tabel 1.

Tabel 1. Hasil angket respon siswa sebelum penelitian.

\begin{tabular}{clcc}
\hline NO & \multicolumn{1}{c}{ ASPEK YANG DIAMATI } & PERSENTASE & KUALIFIKASI \\
1 Belajar matematika menyenangkan. & $71,09 \%$ & Sedang \\
2 Saya tertarik untuk belajar matematika. & $65,63 \%$ & Sedang \\
3 Saya tidak ngantuk menerima penjelasan guru. & $65,63 \%$ & Sedang \\
4 Saya mudah mengerjakan soal matematika. & $60,94 \%$ & Sedang \\
5 Saya berani mengerjakan soal di papan tulis. & $49,22 \%$ & Kurang \\
6 Apabila belum jelas saya berani bertanya kepada guru. & $62,50 \%$ & sedang \\
7 Saya penasaran dengan pelajaran matematika dan ingin & $70,31 \%$ & Sedang \\
belajar lebih baik. . & $63,28 \%$ & Sedang \\
8 Nilai ulangan matematika saya baik. & $20,32 \%$ & Rendah \\
9 Saya bisa menyelesaikan sendiri soal yang diberikan & & \\
oleh guru. & $63,20 \%$ & Sedang \\
10 Saya aktif selama proses pembelajaran & $60,94 \%$ & Sedang \\
11 Belajar metematika terasa tidak monoton. & $55,47 \%$ & Sedang \\
12 Saya tertantang untuk belajar matematika. & $57,81 \%$ & Sedang \\
Selama guru mengajar saya tidak bicara sendiri & $72,66 \%$ & Sedang \\
dengan teman. & $71,88 \%$ & Sedang \\
14 Saya memperhatikan penjelasan guru. & $68,75 \%$ & Sedang \\
Dalam pembahasan soal saya berusaha membantu guru & $76,56 \%$ & Tinggi \\
untuk menyelesaikannnya. & $71,09 \%$ & Sedang \\
17 Saya tidak takut dengan matematika. & & \\
18 Saya mau mengerjakan tugas yang diberikan oleh guru. & $55,47 \%$ & Sedang \\
19 Saya bersemangat belajar matematika & $59,38 \%$ & Sedang \\
\hline 2 Saya rajin belajar matematika & &
\end{tabular}

Berdasarkan dari Tabel 1, terlihat bahwa selama ini siswa masih mempunyai tingkatan yang belum tinggi terhadap minat belajar matematika.
Baru ada satu butir angket yang memiliki tingkatan tinggi, yaitu mau mengerjakan tugas yang diberikan oleh guru selebihnya masih berkualifikasi sedang. 
Desimal, 2 (3), 2019 - 214

Yuliar Astuti Dewi

Rata-rata minat belajar siswa sebelum proses pembelajaran menggunakan bantuan komputer program MS Power Point masih sedang. Ini juga dibuktikan dengan observasi langsung selama proses pembelajaran, siswa masih terlihat belum begitu berminat untuk belajar matematika bahkan ada yang masih merasa takut dan mengalami kesulitan belajar.

Tabel 2. Hasil Observasi Sebelum Tindakan.

\begin{tabular}{clc}
\hline NO & \multicolumn{1}{c}{ ASPEK YANG DIAMATI } & JUMLAH SISWA (\%) \\
1 & Siswa mau mengajukan pertanyaan apabila belum jelas & $0 \%$ \\
2 & Dapat menjawab pertanyaan yang diajukan oleh guru. & $6,25 \%$ \\
3 & Siswa dapat membantu mengerjakan contoh soal & $31,25 \%$ \\
4 & Mau berperan aktif selama KBM berlangsung. & $62,50 \%$ \\
5 & Tidak bicara sendiri selama KBM & $62,50 \%$ \\
6 & Mau mengerjakan soal di buku masing-masing. & $75 \%$ \\
7 & Mau mengerjakan soal di papan tulis. & $0 \%$ \\
8 & Mau mencatat keterangan tambahan. & $50 \%$ \\
9 & Berhasil mengerjakan soal latihan secara individu. & $50 \%$ \\
10 & Dapat menyimpulkan materi pelajaran & $46,88 \%$ \\
\hline
\end{tabular}

Berdasarkan Tabel 2, hasil observasi sebelum penelitian dimulai menunjukkan bahwa rata-rata minat belajar sebesar $38,44 \%$. Dari hasil ini bisa dilihat bahwa minat belajar matematika masih rendah. Sama dengan hasil angket sebelum tindakan juga menunjukkan bahwa minat belajar siswa masih rendah.

Rencana dari penelitian ini adalah dengan menggunakan 2 siklus dan tiaptiap siklus terdiri dari 3 kali pertemuan untuk melakukan kegiatan belajar mengajar dengan pokok bahasan Statistika yaitu kompetensi Ukuran Pemusatan Data dan Ukuran Penyebaran Data.

\section{A. Hasil Penelitian}

Setelah melakukan proses pembelajaran dengan menggunakan bantuan komputer dengan program MS Power Point untuk siklus I dan siklus II serta hasil dari observasi dan wawancara dengan siswa dan guru mitra maka dapat dihasilkan sebagai berikut:

\section{Tindakan pada Siklus I}

a. Perencanaan

Kegaiatan yang pertama kali dalam tahap ini adalah membuat Rencana
Pembelajaran (RP), membuat presentasi dengan program MS Power Point, dan membuat lembar observasi yang akan digunakan selama proses pembelajaran berlangsung. Lembar observasi ini akan diisi oleh teman guru matematika. Selama penulis mengajar, guru matematika lain sebagai mitra mengajar mengamati perilaku siswa, baik perilaku yang positif maupun perilaku yang negative sesuai dengan lembar observasi yang penulis buat. Selain dengan lembar observasi penulis juga menyiapkan dokumen lain yaitu angket dan kamera untuk memotret siswa yang sedang belajar di kelas. Dokumen yang terakhir adalah hasil wawancara penulis dengan guru mitra. Guru mitra diharapkan bisa memberi masukan dan melakukan penilaian terhadap penulis selama melakukan proses pembelajaran di kelas.

b. Pelaksanaan

Pada pertemuan pertama proses pembelajaran sudah memanfaatkan LCD yang berada di ruangan kelas. Penulis juga sudah menyiapkan presentasi dengan program MS Power Point. Dalam hal ini penulis juga menyiapkan laptop untuk mengoperasikan presentasi. 
Dalam awal pembelajaran guru ( penulis ) mengulang kembali secara ringkas pertemuan sebelumnya. Siswa diminta mengingat kembali atau membuka buku tentang macam-macam data. Salah satu siswa diminta menyebutkannya. Setelah siswa mengingat kembali materi sebelumnya, maka guru mulai mengajar materi berikutnya yaitu Ukuran Pemusatan Data. Pada pertemuan pertama ini hanya akan dibahas mengenai mean atau rata-rata hitung, baik mean untuk data tunggal, data tunggal berbobot maupun data kelompok. Pada kegiatan ini guru menjelaskan sudah menggunakan bantuan komputer program MS Power Point tetapi masih menggunakan taraf yang paling sederhana artinya belum ada animasi sama sekali. Penulis juga belum menyisipi gambar-gambar pada setiap slidenya.

Pada pertemuan pertama ini proses pembelajaran berbantuan komputer hanya pada pemberian materi saja. Pada pemberian contoh soal guru masih menggunakan papan tulis, karena pada tahap ini siswa masihdalam tahap penyesuaian. Sebelumnya guru tidak pernah menggunakan bantuan komputer dalam pembelajarannya. Pada pembelajaran ini walapun guru juga ikut mengamati respon siswa. Ternyata semua siswa tertuju pada slide yang guru tayangkan di tembok. Walau mereka masih ada yang berbicara tetapi mata tetap memperhatikan di layar. Ini juga dikuatkan apabila slide diganti slide beikutnya ternyata banyak siswa yang protes karena mereka belum selesai membaca dan memperhatikan materi yang ditayangkan.

Berikutnya adalah pada saat mengerjakan contoh soal, siswa mau membantu menghitung sehingga kelas menjadi lebih hidup dan kegiatan belajar rrkengajar bisa berjalan dua arah. Siswa lebih aktif dan mau mengerjakan soal di papan tulis walaupun masih ditunjuk oleh guru. Sambil guru mengajar, guru mitra memperhatikan respon dan perilaku siswa selama kegiatan pembelajaran dan mencatatnya pada lembar observasi. Siswa dengan respon positif maupun respon negatif semua dicatat. Setelah selesai pertemuan pertama guru minta masukan kepada guru mitra terutama apabila ditemukan kekurangan-kekurangan. Dari masukan ini diharapkan bisa diperbaiki pada pertemuan selanjutnya. Di akhir pertemuan pertama siswa mendapat lembar slide yang telah dijelaskan pada proses pembelajaran pertemuan pertama dan siswa diminta untuk menggandakan sendiri. Jadi pada saat proses pembelajaran siswa cukup memperhatikan penjelasan guru dan tidak perlu mencatat kembali. Siswa hanya mencatat keterangan-keterangan tambahan saja dan mengerjakan soal latihan yang diberikan oleh guru. Semua ini dimaksudkan agar menghemat waktu dan siswa tidak hanya disibukkan mencatat pada saat menerima pelajaran. Kegaiatan ini jugs diberlakukan pada pertemuan kedua dan ketiga nanti.

Pada pertemuan kedua guru mengajar materi median. Sebelumnya guru mengajukan pertanyaan tentang materi pada pertemuan pertama. Pada pemberian pertanyaan ini belum ada satupun siswa yang berani menjawab sendiri tanpa ditunjuk. Mereka hanya berani menjawab secara bersamasama. Setelah ditunjuk oleh guru baru ada siswa berani menjawab walapun masih membaca buku. Berikutnya adalah membahas PR. Pada pembahasan PR ini karena belum ada siswa yang berani sendiri menulis di papan tulis maka gurulah yang menulisnya. Pada pertemuan kedua ini proses pembelajaran berbantuan komputer program MS Power Point sudah ditambah dengan animasi. Pada tahap ini siswa lebih banyak yang memperhatikan, karena mereka begitu 
tertarik dengan animasi yang diberikan. Kalimat demi kalimat yang ditulis begitu hidup sehingga frekeuensi siswa untuk bicara sendiri sudah berkurang. Tetapi tetap masih ada yang bicara sendiri terutama siswa yang duduk dibelakang. Dengan cara mengingatkan siswa yang masih bicara sendiri diminta untuk lebih memperhatikan penjelasan guru. Walaupun guru mitra duduk di belakang tetapi bagi siswa yang suka bicara mesih sulit untuk didiamkan. Pada pertemuan kedua ini pemberian materi dan contoh soal mennggunakan komputer program MS Power Point. Jadi ada penambahan waktu dalam penggunaan komputer ini dibanding pada pertemuan pertama. Peran aktif siswa sudah bertambah, dari sebelumnya hanya sedikit yang mau merespon penjelasan guru. Ada satu siswa yang sudah berani dan mau bertanya kepada guru. Dari satu siswa ini guru sangat memberi penghargaan kepada siswa tersebut dengan pujian agar siswa yang lainnya mau bertanya.

Untuk pertemuan ketiga guru memberi penjelasan tentang modus. Sebelum sampai pada pemberian materi guru menanyakan arti median kepada salah seorang siswa, ternyata sudah ada yang bisa menjawab tanpa melihat buku. Ini menunjukkan sudah ada peningkatan keberanian walapun belum signifikan. Proses pembelajaran berbantuan komputer program MS Power Point tetap menggunakan animasi dan ditambah dengan gambar pada setiap slidenya. Gambar-gambar ini bertujuan untuk lebih meningkatkan minat siswa dalam proses pembelajaran. Kalau sebelumnya hanya berupa animasi tetapi pada pertemuan ini karena sudah ditambah dengan gambar maka respon siswa ternyata juga lebih baik. Walapun gambar tersebut tidak berhubungan dengan matematika tetapi setidaknya sudah ada suasana lain di dalam kelas. Ternyata siswa sangat merespon silde yang ditayangkan di depan. Mereka begitu senang dan frekuensi bicara sudah sangat berkurang. Siswa yang biasanya bicara sendiri ternyata pada pertemuan ketiga ini sudah mulai diam.

Pada saat guru memberikan soal sudah ada siswa yang berani menjawabnya di papan tulis, tetapi masih ragu dalam mengerjakannya. Dengan memberikan motivasi dan bantuan penyelesaian siswa dapat menyelesaikan soal dengan benar. Pada pertemuan ketiga ini sudah dua siswa yang berani menjawab langsung soal di papan tulis. Ini menunjukkan bahwa penggunakan komputer program MS Power Point dan penambahan animasi ataupun gambar dalam setiap slidenya ternyata dapat meningkatkan minat belajar siswa.

\section{c. Analisis Hasil Observasi}

Setelah observasi pada siklus I dilaksanakan maka langkah berikutnya adalah menganalisis. Berikut hasil observasi dari 32 siswa. 
Desimal, 2 (3), 2019 - 217

Yuliar Astuti Dewi

Tabel 3. Hasil observasi terhadap siswa selama proses pembelajaran pada siklus I.

\begin{tabular}{|c|c|c|c|c|c|}
\hline \multirow[b]{2}{*}{ NO } & \multirow[b]{2}{*}{ ASPEK YANG DIAMATI (K) } & \multicolumn{4}{|c|}{ JUMLAH SISWA (\%) } \\
\hline & & $\begin{array}{l}\text { Perte- } \\
\text { muan } 1\end{array}$ & $\begin{array}{l}\text { Perte- } \\
\text { muan } 2\end{array}$ & $\begin{array}{l}\text { Perte- } \\
\text { muan } 3\end{array}$ & $\begin{array}{l}\text { Rata- } \\
\text { rata }\end{array}$ \\
\hline 1 & $\begin{array}{l}\text { Siswa mau mengajukan pertanyaan } \\
\text { apabila belum jelas }\end{array}$ & $0 \%$ & $6,25 \%$ & $12,5 \%$ & $9,38 \%$ \\
\hline 2 & $\begin{array}{l}\text { Dapat menjawab pertanyaan yang } \\
\text { diajukan oleh guru. }\end{array}$ & $6,25 \%$ & $9,38 \%$ & $21,88 \%$ & $12,50 \%$ \\
\hline 3 & $\begin{array}{l}\text { Siswa dapat membantu mengerjakan } \\
\text { contoh soal }\end{array}$ & $37,5 \%$ & $46,88 \%$ & $50 \%$ & $44,79 \%$ \\
\hline 4 & $\begin{array}{l}\text { Mau berperan aktif selama KBM } \\
\text { berlangsung. }\end{array}$ & $65,63 \%$ & $68,75 \%$ & $68,75 \%$ & $67,71 \%$ \\
\hline 5 & Tidak bicara sendiri selama KBM & $68,75 \%$ & $81,25 \%$ & $68,75 \%$ & $72,92 \%$ \\
\hline 6 & Mau mengerjakan soal di buku & $75 \%$ & $81,25 \%$ & $78,13 \%$ & $78,13 \%$ \\
\hline 7 & Mau mengerjakan soal di papan tulis. & $0 \%$ & $6,25 \%$ & $6,25 \%$ & $6,25 \%$ \\
\hline 8 & , Mau mencatat keterangan tambahan. & $81,25 \%$ & $87,50 \%$ & $87,50 \%$ & $85,42 \%$ \\
\hline 9 & $\begin{array}{l}\text { Berhasil mengerjakan soal latihan secara } \\
\text { individu. }\end{array}$ & $78,13 \%$ & $84,38 \%$ & $84,38 \%$ & $82,30 \%$ \\
\hline 10 & $\begin{array}{l}\text { Dapat menyimpulkan materi } \\
\text { pelajaran }\end{array}$ & $56,25 \%$ & $65,63 \%$ & $71,88 \%$ & $64,59 \%$ \\
\hline
\end{tabular}

Keterangan:

$\mathrm{P} 1$ = pertemuan ke -1

$\mathrm{P} 2$ = pertemuan ke-2

$\mathrm{P} 3=$ pertemuan $\mathrm{ke}-3$

Dari hasil observasi di atas dapat diketahui bahwa pada butir observasi atau respon siswa ke 1, 2, 3 dan ke 10 ( Kl, K2, K3, K10 ) ada kenaikan persentasi pada tiap pertemuan. Ini menunjukkan bahwa siswa mengalami kenaikan semangat dalam proses pembelajaran matematika, walaupun kenaikan itu tidak begitu signifikan. Pada butir kegiatan ke empat pada pertemuan kedua dan ketiga belum ada peningkatan sedangkan pada butir observasi ke 5 dan 6 ada kenaikan pada pertemuan kedua, tetapi pada pertemuan ketiga ada penurunan. Pada butir observasi ke 7 sampai 9 pada pertemuan kedua ada kenaikan persentasi tetapi pada pertemuan ketiga persentase keaktifan siswa tetap sehingga bisa dikatakan bahwa proses pembelajaran dengan gambar pada setiap slidenya untuk beberapa siswa kurang menarik perhatian, atau belum $100 \%$ siswa tertarik. Sementara pada butir observasi ke 10 yaitu siswa dapat menyimpulkan materi pelajaran pada pertemuan pertama sampai pertemuan ketiga ada kenaikan persentase. Secara individual kenaikan minat belajar pada observasi siklus I adalah: 
Desimal, 2 (3), 2019 - 218

Yuliar Astuti Dewi

Tabel 4. Banyaknya siswa yang mengalami

kenaikan minat belajar pada observasi siklus I :

\begin{tabular}{clc}
\hline NO & \multicolumn{1}{c}{ ASPEK YANG DIAMATI } & JUMLAH SISWA \\
1 & Siswa mau mengajukan pertanyaan apabila belum jelas & 4 \\
2 & Dapat menjawab pertanyaan yang diajukan oleh guru. & 5 \\
3 & Siswa dapat membantu mengerjakan contoh soal & 4 \\
4 & Mau berperan aktif selama KBM berlangsung. & 1 \\
5 & Tidak bicara sendiri selama KBM & 0 \\
6 & Mau mengerjakan soal di buku masing- masing. & 1 \\
7 & Mau mengerjakan soal di papan tulis. & 2 \\
8 & Mau mencatat keterangan tambahan. & 2 \\
9 & Berhasil mengerjakan soal latihan secara individu. & 2 \\
10 & Dapat menyimpulkan materi pelajaran & 5 \\
\hline
\end{tabular}

Berdasarkan Tabel 4, Secara individu jumlah siswa terbanyak yang mengalami kenaikan minat belajar selama KBM berlangsung adalah pada butir kegitan dapat menyimpulkan materi pelajaran. Dari hasil observasi langsung memang terlihat pada sag guru menanyakan pada siswa hasil kesimpulan mereka dan pada butir dapat menjawab pertanyaan yang diajukan oleh guru, ternyata siswa bisa menjawab dengan lancar. Sebaliknya hasil observasi yang mengalami kenaikan minat belajar terendah yaitu pada butir kegiatan tidak bicara sendiri. Pada butir ini ternyata siswa belum bisa berhenti bicara pada saat KBM berlangsung terutama mereka yang duduk di belakang. Hal ini menjadi catatan kusus guru agar di pertemuan berikutnya bisa diperbaiki lagi. Butir lain yang meningkat minat belajarnya berturut-turut adalah mau berperan aktif selama KBM berlangsung, mau mengerjakan soal, diikuti mau mengerjakan soal di papan tulis, mau mencatat dan mau mengerjakan soal secara individu.
Berikutnya adalah pada butir siswa mau bertanya, mau membantu guru menyelesaikan contoh soal. Walaupun kenaikan minat belajar itu tidak semua sama pada setiap aspek yang diamati, bahkan ada yang tidak mengalami kenaikan tetapi secara umum bahwa proses pembelajaran berbantuan komputer program MS Power Point pada siklus I ini dapat meningkatkan semangat belajar siswa. Ini dibuktikan dengan bertambahnya keaktifan siswa selama proses pembelajaran.

\section{d. Analisis Hasil Angket \\ Setelah selesai proses pembelajaran dengan bantuan} komputer program MS Power Point pada siklus I selesai maka dilanjutkan dengan pemberian nagket tentang minat belajar selama siklus I. Angket ini harus diisi oleh seluruh siswa. Siswa diharapkan dapat mengisinya sesuai dengan isi hatinya tanpa ada pengaruh dari pihak lain, baik dari siswa ataupun guru. Berikut ini hasil angket pada akhir siklus I. 
Desimal, 2 (3), 2019 - 219

Yuliar Astuti Dewi

Tabel 5. Hasil angket respon siswa akhir siklus I

\begin{tabular}{|c|c|c|c|}
\hline NO & ASPEK YANG DIAMATI & PERSENTASE & KUALIFIKASI \\
\hline 1 & Belajar matematika menyenangkan. & $72,66 \%$ & Sedang \\
\hline 2 & Saya tertarik untuk belajar matematika. & $60,64 \%$ & Sedang \\
\hline 3 & Saya tidak ngantuk menerima penjelasan guru. & $56,25 \%$ & Sedang \\
\hline 4 & Saya mudah mengerjakan soal matematika. & $78,13 \%$ & Sedang \\
\hline 5 & Saya berani mengerjakan soal di papan tulis. & $51,56 \%$ & Kurang \\
\hline 6 & Apabila belum jelas saya berani bertanya kepada guru. & $64,84 \%$ & Sedang \\
\hline 7 & $\begin{array}{l}\text { Saya penasaran dengan pelajaran matematika dan } \\
\text { ingin belajar lebih baik. }\end{array}$ & $72,66 \%$ & Sedang \\
\hline 8 & Nilai ulangan matematika saya baik. & $70,31 \%$ & Sedang \\
\hline 9 & Saya bisa menyelesaikan sendiri soal yang diberikan & $67,19 \%$ & Rendah \\
\hline 10 & Saya aktif selama proses pembelajaran matematika & $73,44 \%$ & Sedang \\
\hline 11 & Belajar metematika terasa tidak monoton. & $67,19 \%$ & Sedang \\
\hline 12 & Saya tertantang untuk belajar matematika. & $59,38 \%$ & Sedang \\
\hline 13 & Selama guru mengajar saya tidak bicara sendiri & $65,63 \%$ & Sedang \\
\hline 14 & Saya memperhatikan penjelasan guru. & $83,59 \%$ & Sedang \\
\hline 15 & $\begin{array}{l}\text { Dalam pembahasan soal saya berusaha membantu } \\
\text { guru untuk menyelesaikannnya. }\end{array}$ & $77,34 \%$ & Sedang \\
\hline 16 & Saya tidak takut dengan matematika. & $75,78 \%$ & Sedang \\
\hline 17 & $\begin{array}{l}\text { Saya mau mengerjakan tugas yang diberikan oleh } \\
\text { guru. }\end{array}$ & $77,34 \%$ & Tinggi \\
\hline 18 & Saya memiliki jadwal rutin untuk belajar matematika. & $75,78 \%$ & Sedang \\
\hline 19 & Saya bersemangat belajar matematika & $74,22 \%$ & Sedang \\
\hline 20 & Saya rajin belajar matematika & $64,06 \%$ & Sedang \\
\hline
\end{tabular}

e. Wawancara

Setelah selesai pertemuan ketiga pada siklus I ini maka langkah selanjutnya adalah wawancara dengan siswa mapupun dengan guru mitra. Berikut ini hasil wawancaranya.

1) Wawancara dengan siswa

Pada wawancara dengan siswa, guru menunjuk salah satu siswa untuk menjawab pertanyaan yang guru ajukan mengenai proses pembelajaran pada siklus I. Ternyata siswa sangat mendukung dengan proses pembelajaran berbantuan komputer program MS Power Point ini dan mengusulkan untuk pertemuan berikutnya tetap menggunakan komputer. Menurut siswa proses pembelajaran ini baru pertama kalinya dilakukan untuk kelas tersebut terutama untuk pelajaran matematika. Selama ini siswa menerima pelajaran matematika dengan cara yang sangat umum sekali tanpa bantuan media pembelajaran yang lebih baik. Siswa merasa ada yang lebih baru dan lebih baik daripada menjelaskan tanpa menggunakan komputer. Apalagi setelah ditambah animasi dan gambar pada setiap slidenya siswa menjadi tidak ngantuk. Siswa juga mengutarakan bahwa teman-temanya mendukung proses pembelajaran ini. Kekurangan yang diterima siswa adalah kelas menjadi agak gelap karena korden di setiap jendela harus ditutup agar gambar pada slidernyalebih jelas. Untuk siswa yang berkaca mata minus suasana ini agak mengganggu. Siswa yang tadinya enggan bertanya ternyata sekarang sudah berani bertanya apabila ada yang belum jelas. Siswa tersebut juga merasakan lebih mudah memahami penjelasan guru setelah ditayangkan lewat program Power Point. Penyelesaian contoh soal jangan hanya diselesaikan lewat tayangan slide tetapi harus juga ditulis di papan tulis sehingga proses pemahaman penyelesian soal 
lebih baik. Karena apabila hanya diselesaikan lewat tayangan slide siswa masih kesulitan dalam menerima penjelasan.

2) Wawancara dengan guru mitra. Guru mitra memberi padangan yang positif tentang proses pembelajaran melalui media berbantuan komputer ini. Dengan cara ini siswa lebih memperhatikan dan frekuensi bicara sendiri sudah sangat berkurang. Penjelasan tiap slidenya lebih memudahkan siswa untuk memahami. Usulan dari guru mitra adalah pada pertemuan siklus berikutnya adalah tetap menggunakan media pembelajaran berbantuan komputer dan proses penayangan tiap slidenya jangan terlalu cepat, karena banyak siswa yang belum selesai memahami tetapi slide sudah diganti dengan slide berikutnya sehingga siswa hams berkali-kali minta ditayangkan ulang.Dari pengamatan guru mitra jelas terlihat bahwa minat belajar siswa bertambah, siswa begitu antusias memperhatikan penjelasan guru dan mereka juga berminat untuk mengerjakan semua tugas yang diberikan oleh guru.

\section{f. Refleksi}

Dari hasil observasi, wawancara dengan siswa dan wawancara dengan guru mitra yang telah dilakukan pada siklus I ada beberapa masukan atau masalah yang muncul yaitu proses penayangan slide terlalu cepat sehingga siswa harus minta guru untuk mengulang kembali slide yang telah diganti. Karena penayangan silde akan lebih jelas ditempat yang gelap maka korden pada ruangan kelas harus ditutup dan sebagian lampu dimatikan, ini mengakibatkan siswa yang berkaca mata minus merasa terganggu dan sulit untuk menulis atau mengerjakan soal di buku. Siswa belum begitu saja bisa menghentikan bicara terutama siswa yang duduk di belakang. Walaupun persentasi sudah berkurang tetapi belum bisa $100 \%$ siswa diam dan berkonsentrasi pada proses pembelajaran. Siswa untuk maju mengerjakan soal di papan tulis masih sedikit, belum banyak yang punya keberanian dengan sukarela mengerjakan di papan tulis. Proses penyelesaian latihan soal yang hanya ditayangkan di tayangan slide dan guru menjelaskannya secara lisan ternyata siswa masih kurang begitu paham.

Perbaikan-perbaikan atas masalah tersebut adalah Proses penayangan slide perlu ditambah waktunya, sebelum guru mengganti dengan slide berikutnya perlu minta persetujuan dari siswa atau guru mengamati siswa apakah mereka sudah selesai dalam memahami atau membaca tulisan yang ada di slide. Penerangan di kelas perlu ditambah sehingga ruangan kelas tidak begitu gelap agar siswa mupun guru tidak belajar di tempat yang agak gepal dan siswa yang berkaca mata minus tidak mengalami kesulitan dalam menerima pelajaran. Guru harus lebih perhatian terhadap siswa terutama yang duduk di belakang agar siswa yang suka bicara bisa lebih perhatian dalam proses pembelajaran dan tidak mengganggu temannya. Siswa perlu diberi motivasi yang lebih tinggi lagi agar keberanian menjawab soal di papan tulis dapat ditingkatkan. Mereka harus diberi pengertian bahwa siswa tidak perlu takut apabila mereka salah dalam mengerjakan soal. Proses penyelesaian latihan soal perlu ditulis kembali oleh guru di papan tulis agar siswa lebih mudah dalam menyerapnya dan tidak kesulitan untuk mengerjakan soal latihan.

\section{Tindakan Pada Siklus II}

a. Perencanaan

Tahapan-tahapan yang dilakukan ilada sklus II pada dasarnya sama dengan siklus I dan ditambah perbaikan- 
perbaikan yang diperlukan dan kekurangankekurangan yang harus dilaksanakan oleh siswa agar minat belajar siswa lebih baik lagi. Untuk siswa yang masih perlu mendapat perhatian adalah (1) Siswa mau bertanya kepada guru (2) Dapat menjawab pertanyaan guru. (3) Siswa dapat membantu menyelesaikan soal (4) Mau mengerjakan soal di papan tulis dengan sukarela tanpa hams diperintah oleh guru (5) Guru memberi perhatian lebih pada siswa yang duduk di belakang. Sedangkan untuk proses pembelajaran yang harus diperbaiki adalah (1) Guru jangan terlalu cepat mengganti slide (2) Penerangan kelas perlu ditambah (3) Proses penyelesian latihan soal masih perlu diperjelas dengan menulis di papan tulis.

\section{b. Pelaksanaan}

Sesuai dengan rencana yang telah diuraikan di atas maka pembelajaran pada siklus II ini tetap menggunakan media pembelajaran berbantuan komputer program MS Power Point. Pertemuan pertama guru menjelaskan materi Ukuran Penyebaran Data sub kompetensi jangkauan dan simpangan rata-rata. Pada penjelasan kali ini guru masih menggunakan animasi dan gambar-gambar pada tiap slidenya. Agar lebih menarik maka gambar juga diberi animasi seperti pada tulisan tulisan di tiap slide. Pada contoh soal guru menyisipkan juga hyperlink. Pada kondisi jawaban benar maka diberi sound tepuk tangan (applaus) clan gambar yang menyegarkan siswa agar siswa bisa lebih tertarik dan berminat lagi untuk menjawab soal. Karena pada siklus I semangat siswa untuk mau mengerjakan soal di papan tulis belum banyak maka pada siklus II ini guru akan memberi motivasi dan semangat serta pujian agar siswa berani maju tanpa harus takut salah.

Pada hasil refleksi di siklus I maka pada pertemuan pertama siklus II ini perbaikan-perbaikan sudah dilakukan yaitu pengantian tiap slidenya tidak terlalu cepat dan ruangan kelas ditambah penerangannya serta penyelesaian soal maupun contoh soal yang diberikan oleh guru akan dipertegas dengan menulis di papan tulis. Ternyata setelah diadakan perbaikan maka sudah tidak ada lagi keluhan dari siswa dan siswa yang berkacamata minus pun tidak lagi terganggu. Selain itu siswa yang bisa menjawab pertanyaan yang diajukan Kegaiatan perencanaan pada siklus II ini dimulai dengan menyusun Rencana Pembelajaran (RP) untuk kompetensi Ukuran Penyebaran Data yaitu jangkauan, simpangan rata-rata, simpangan baku, dan kuartil. Untuk fasilitas media pembelajaran yang dipersiapkan adalah LCD, laptop, bahan ajar alat lain yang mendukung. Selain itu peneliti juga menyiapkan presentasi yang akan diajarkan pada pertemuan 1 sampai pertemuan 3 dengan program MS Power Point. Seperti pada siklus I peneliti masih perlu menambah kelengkapan data dengan menggambil gambar siswa atau guru selama proses pembelajaran dengan kamera. Selain kamera peneliti menyiapkan lembar observasi dan rencana pertanyian yang harus dijawab untuk siswa dan guru mira pada wawancara. Pada akhir siklus II peneliti menyiapkan angket yang harus diisi oleh seluruh siswa untuk mengetahui apakan ada peningkatan minat belajar siswa pada matematika setelah siswa mendapat pembelajaran dengan bantuan komputer program MS Power Point. Selama proses pembelajaran pada pertemuan pertama sampai ketiga pada siklus II ini siswa cukup memperhatikan penjelasan guru sambil melihat tayangan slide di layar. Siswa hanya mencatat hal-hal yang dirasa perlu saja atau keteranganketerangan tambahan. Bantuan guru 
mitra untuk mengamati respon siswa selama proses pembelajaran masih diperlukan. Guru mitra mengamati siswa setiap saat dan mencatatnya pada lembar observasi. Untuk pertemuan kedua sub kompetensi yang diberikan adalah menjelaskan simpangan baku. Pertemuan kedua sama dengan pertemuan pertama yaitu tetap menggunakan bantuan komputer program MS Power Point disertai dengan animasi dan hyperlink pada soal pilihan ganda. Berdasarkan hasil pengamatan sementara oleh peneliti (guru) dan guru mitra pada pertemuan kedua ini sudah terlihat ada peningkatkan minat siswa untuk mempelajari matematika dan ini dibuktikan dengan banyaknya siswa yang mau mengerjakan soal dan bisa menjawab dengan benar, bisa merangkum materi pelajaran sendiri dan selama guru menyelesaikan soal di papan tulis hampir semua siswa ikut terlibat didalamnya.

Pertemuan ketiga adalah menjelaskan kuartil. Ternyata respon siswa sangat tinggi. Semua siswa mengerjakan pekerjaan rumah dan bisa menjawabnya dengan benar. Selama proses pembelajaran siswa kelihatan aktif dan deretan siswa yang duduk di belakang tetap kelihatan aktif memperhatikan penjelasan guru dan konsentrasi di layar presentasi.

\section{c. Analisis Hasil Observasi}

Seperti halnya di siklus I maka pada siklus II ini akan ditampilkan hasil observasi guru mitra terhadap siswa selama mengikuti proses pembelajaran dengan bantuan komputer program MS Power Point. Hasil yang ditampilkan juga berupa jumlah siswa yang aktif dan persentasinya. Format dan uraian respon siswa sama dengan yang ada di siklus I.

Proses pengamatan siswa pada siklus II ini lebih focus pada siswa yang duduk di belakang, karena dari hasil pengamaan siklus I siswa yang duduk di belakng masing belum bisa tenang dan masih suka bicara sendiri. Guru mitra tak henti-hentinya menegur siswa yang masih bicara sendiri. Ternyata dengan teguran guru mitra di akhir siklus II frekuensi bicara sendiri pada saat pelajaran sudah jauh berkurang. Demikian juga pemberian semangat kepada siswa agar tidak perlu takut untuk mengerjakan soal di papan tulis mendapat respon yang baik dari siswa. 
Desimal, 2 (3), 2019 - 223

Yuliar Astuti Dewi

Tabel 6. Hasil observasi pada proses pembelajaran berbantuan komputer program MS Power Point pada siklus II.

\begin{tabular}{|c|c|c|c|c|c|}
\hline \multirow[b]{2}{*}{ NO } & \multirow[b]{2}{*}{ ASPEK YANG DIAMATI(K) } & \multicolumn{4}{|c|}{ JUMLAH SISWA (\%) } \\
\hline & & $\begin{array}{l}\text { Perte- } \\
\text { muan } 1\end{array}$ & $\begin{array}{l}\text { Perte- } \\
\text { muan } 2\end{array}$ & $\begin{array}{l}\text { Perte- } \\
\text { muan } 3\end{array}$ & Rata-rata \\
\hline 1 & $\begin{array}{l}\text { Siswa maumengajukanpertanyaan } \\
\text { apabila belum jelas }\end{array}$ & $12,5 \%$ & $12,5 \%$ & $18,75 \%$ & $14,58 \%$ \\
\hline 2 & $\begin{array}{l}\text { Dapat menjawab pertanyaan yang } \\
\text { diajukan oleh guru. }\end{array}$ & $40,63 \%$ & $50 \%$ & $81,25 \%$ & $57,29 \%$ \\
\hline 3 & $\begin{array}{l}\text { Siswa dapat membantu mengerjakan } \\
\text { contoh soal }\end{array}$ & $50 \%$ & $71,88 \%$ & $84,38 \%$ & $68,75 \%$ \\
\hline 4 & $\begin{array}{l}\text { Mau berperan aktif selama KBM } \\
\text { berlangsung. }\end{array}$ & $81,25 \%$ & $87,50 \%$ & $100 \%$ & $89,58 \%$ \\
\hline 5 & Tidak bicara sendiri selamaKBM & $84,38 \%$ & $93,75 \%$ & $93,75 \%$ & $90,63 \%$ \\
\hline 6 & $\begin{array}{l}\text { Mau mengerjakan soal di buku } \\
\text { masing masing. }\end{array}$ & $100 \%$ & $100 \%$ & $100 \%$ & $100 \%$ \\
\hline 7 & Mau mengerjakan soal dipapan tulis. & $6,25 \%$ & $12,50 \%$ & $12,50 \%$ & $10,42 \%$ \\
\hline 8 & Mau mencatat keterangan tambahan. & $87,50 \%$ & $93,75 \%$ & $96,88 \%$ & $92,71 \%$ \\
\hline 9 & $\begin{array}{l}\text { Berhasil mengerjakan soal latihan } \\
\text { secara individu. }\end{array}$ & $93,75 \%$ & $100 \%$ & $100 \%$ & $97,92 \%$ \\
\hline 10 & $\begin{array}{l}\text { Dapat menyimpulkan materi } \\
\text { pelajaran }\end{array}$ & $68,75 \%$ & $78,13 \%$ & $90,63 \%$ & $79,17 \%$ \\
\hline
\end{tabular}

Berdasarkan Tabel 6, hasil observasi pada siklus II terlihat bahwa selalu ada kenaikan minat belajar siswa terhadap matematika dibanding pada pertemuan pada siklus I. Pada siklus II ini butir1 respon siswa dari pertemuan kedua ke pertemuan ketiga ada kenaikan sedangkan pada pertemuan pertama ke pertemuan kedua tetap. Untuk butir 4,5 , 6,8 , dan 10 respon siswa tiap pertemuan selalu ada kenaikan minat belajar. Sedangkan pada butir ke 5, 6, 7, dan 9 untuk pertemuan pertama dan pertemuan kedua ada kenaikan sedangkan pertemuan kedua ke pertemuan ketiga tetap. Ada dua hal yang utama pada siklus II ini yaitu pada saat proses pembelajaran dengan bantuan komputer program MS Power Point selain dengan animasi pada tulisan tetapi animasi juga diberikan pada gambar pada tiap slidenya. Selain itu pada soal pilihan ganda jawaban dibuat dengan hyperlink. Ternyata hal ini sangat menarik perhatian siswa. Siswa kelihatan lebih antusias dalam menerima pelajaran.

Jadi dapat disimpulkan bahwa proses pembelajaran berbantuan komputer dapat meningkatkan minat belajar siswa terhadap matematika. Hal ini dapat dilihat pada tiap butir respon siswa (kegiatan siswa) rata-rata mengalami kenaikan minat pada tiap pertemuan. Secara individual banyaknya siswa yang mengalami kenaikan minat belajar pada siklus II untuk masingmasing aspek pengamatan dapat ditampilkan seperti yang tercantum pada Tabel 7: 
Desimal, 2 (3), 2019 - 224

Yuliar Astuti Dewi

Tabel 7. Banyaknya siswa yang mengalami kenaikan minat belajar hasil observasi pada siklus II :

\begin{tabular}{llc}
\hline NO ASPEK YANG DIAMATI & JUMLAH SISWA \\
1 Siswa mau mengajukan pertanyaan apabila belum jelas & 2 \\
2 & Dapat menjawab pertanyaan yang diajukan oleh guru. & 13 \\
3 & Siswa dapat membantu mengerjakan contoh soal & 11 \\
4 & Mau berperan aktif selama KBM berlangsung. & 6 \\
5 & Tidak bicara sendiri selama KBM & 3 \\
6 & Mau mengerjakan soal di buku masing-masing. & 0 \\
7 & Mau mengerjakan soal di papan tulis. & 2 \\
8 & Mau mencatat keterangan tambahan. & 3 \\
9 & Berhasil mengerjakan soal latihan & secara \\
individu. & & 2 \\
10 Dapat menyimpulkan materi pelajaran & \\
\hline
\end{tabular}

Dari Tabel 7 di atas siswa yang banyak mengalami kenaikan minat belajar adalah pada butir ke 2 yaitu pada aspek dapat menjawab pertanyaan yang diajukan oleh guru disini ada 13siswa yang menunjukkan kenaikan minat belajar. Sedangkan pada tingakt kenaikan yang terendah adalah pada spek pengamatan butir ke 6 yaitu mau mengerjakan soal di buku masingmasing. Pada kenaikan yang terendah ini bukan berati bahwa tidak ada kenaikan minat belajar, tetapi karena banyaknya siswa yang mau mengerjakan soal di buku masing-masing masih sama dengan pertemuan sebelumnya. Untuk siswa yang mau membantu guru dalalam negerjakan contoh soal berada di uruta kedua kenaikan minat belajar dengan menggunakan bantuan komputer program MS Power Point.

\section{d. Analisis Hasil Angket Siswa}

Setelah proses pembelajaran berbantuan komputer program MS Power Point pada pada enam pertemuan pertama atau pada siklus I dan siklus II maka diadakan lagi pengisian angket. Angket ini berisi pertanyaan-pertanyaan seperti pada angket sebelum tindakan. Harapan dari pemberian angket kedua ini untuk mengetahui seberapan besar kenaikan minat belajar siswa sebelum tindakan dan setelah tindakan. Sebetulnya selama proses pembelajaran dengan bantuan computer program MS Power Point ini sudah terlihat bahwa minat belajar siswa bertambah. Dalam observasi siklus I dan siklus II sudah tercatat bahwa respon siswa terhadap proses pembelajaran sudah lebih baik. Agar hasil observasi tersebut lebih jelas maka dipertegas dengan pemberian angket.

Selama proses pengisian angket siswa dituntut mengisi sesuai dengan isi hatinya, karena hasil dari pengisian angket ini tidak mempengaruhi penilaian. Siswa tidak perlu ragu atau takut kepada guru. Pada pengisian angket sebelum tindakan masih ada siswa yang diskusi dengan temannya, tetapi untuk pengisian angket pada akhir tindakan ini sudah tidak ada lagi diskusi, siswa menulis sesuai dengan apa yang dirasakannya selama proses pembelajaran. 
Desimal, 2 (3), 2019 - 225

Yuliar Astuti Dewi

Tabel 8. Hasil angket siswa setelah tindakan pada siklus II

\begin{tabular}{|c|c|c|c|}
\hline NO & ASPEK YANG DIAMATI & PERSENTASE & KUALIFIKASI \\
\hline 1 & Belajar matematika menyenangkan. & $85,94 \%$ & Tinggi \\
\hline 2 & Saya tertarik untuk belajar matematika. & $79,69 \%$ & Tinggi \\
\hline 3 & Saya tidak ngantuk menerima penjelasan guru. & $80,47 \%$ & Tinggi \\
\hline 4 & Saya mudah mengerjakan soal matematika. & $81,25 \%$ & Tinggi \\
\hline 5 & Saya berani mengerjakan soal di papan tulis. & $72,66 \%$ & Sedang \\
\hline 6 & $\begin{array}{l}\text { Apabila belum jelas saya berani bertanya kepada } \\
\text { guru. }\end{array}$ & $68,75 \%$ & Sedang \\
\hline 7 & $\begin{array}{l}\text { Saya penasaran dengan pelajaran } \\
\text { matematika dan ingin belajar lebih baik. }\end{array}$ & $75,78 \%$ & Tinggi \\
\hline 8 & Nilai ulangan matematika saya baik. & $77,34 \%$ & Tinggi \\
\hline 9 & $\begin{array}{l}\text { Saya bisa menyelesaikan sendiri soal yang } \\
\text { diberikan oleh guru. }\end{array}$ & $74,22 \%$ & Sedang \\
\hline 10 & $\begin{array}{l}\text { Saya aktif selama proses } \\
\text { matematika }\end{array}$ & $77,34 \%$ & Tinggi \\
\hline 11 & Belajar metematika terasa tidak monoton. & $68,75 \%$ & Sedang \\
\hline 12 & Saya tertantang untuk belajar matematika. & $58,59 \%$ & Sedang \\
\hline 13 & $\begin{array}{l}\text { Selama guru mengajar saya } \\
\text { sendiri dengan teman. }\end{array}$ & $78,13 \%$ & Tinggi \\
\hline 14 & Saya memperhatikan penjelasan guru. & $81,25 \%$ & Tinggi \\
\hline 15 & $\begin{array}{l}\text { Dalam pembahasan soal saya berusaha } \\
\text { membantu guru untuk menyelesaikannnya. }\end{array}$ & $76,56 \%$ & Tinggi \\
\hline 16 & Saya tidak takut dengan matematika. & $73,44 \%$ & Sedang \\
\hline 17 & $\begin{array}{l}\text { Saya mau mengerjakan tugas yang diberikan oleh } \\
\text { guru. }\end{array}$ & $82,81 \%$ & Tinggi \\
\hline 18 & $\begin{array}{l}\text { Saya memilili jadwal rutin untuk belajar } \\
\text { matematika. }\end{array}$ & $82,03 \%$ & Tinggi \\
\hline 19 & Saya bersemangat belajar matematika & $81,25 \%$ & Tinggi \\
\hline \multirow[t]{2}{*}{20} & Saya rajin belajar matematika & $81,25 \%$ & Tinggi \\
\hline & Rata-rata & $76,88 \%$ & Tinggi \\
\hline
\end{tabular}


Perhitungan presentase setiap indikator dapat dihitung dengan rumus pada metode penelitian. Dari hasil angket pada siklus II ini ternyata hasilnya tidak jauh berbeda dari hasil observasi pada siklus II. Setelah proses pembelajaran menggunakan bantuan computer program MS Power Point banyak sekali kemajuan yang didapatkan. Pada setiap butir pengamatan semuanya mengalami kenaikan presentase, walapun kenaikan itu tidak terlalu besar. Berikut ini ditampilkan hasil angket pada akhir pertemuan ketiga atau pertemuan terakhir dari penelitian.

Dari hasil angket respon siswa di atas ada 6 item respon yang memiliki kualifikasi sedang dan 14 item yang memiliki kualifikasi tinggi. Ini dapat disimpulkan bahwa sebagian besar siswa memiliki respon positif selama guru melakukan proses pembelajaran dengan bantuan komputer program MS Power Point. Ada peningkatan minat belajar siswa dibanding sebelum menggunakan bantuan komputer.

Jadi pada hasil angket respon siswa terhadap proses pembelajaran berbantuan komputer dengan program MS Power Point ini rata-rata mengalami kenaikan kualifikasi dibanding pada kegiatan pra penelitiaan. Pada hasil angket pra penelitian sebagian besar hasilnya adalah berkualifikasi sedang, sedangkan pada akhir penelitian ini sebagian besar berkualifikasi tinggi. Hasil kualifikasi ini terlihat pada persentasi pada tiap butir respon siswa, hampir semuanya diatas 75 $\%$. Ini menunjukkan bahwa sebelum penelitian dengan sesudah penelitian minat belajar siswa mengalami kenaikan.

\section{e. Wawancara}

Wawancara dilakukan terhadap siswa dan guru mitra sebagai pengamat selama proses pembelajaran berlangsung. Berikut ini hasil wawancaranya: Wawancara ini dilaksanakan setelah proses pembelajaran siklus II selesai. Menurut siswa pada siklus
II ini sudah ada perbaikan atau revisi. Jadi keluhan siswa pada siklus I tidak ditemukan lagi pada siklus II. Siswa bertambah semangat pada siklus II ini karena selain banyak animasi ternyata guru juga menyisipkan hyperlink pada tiap soal pilihan gandanya. Dan menurut guru mitra, karena pada siklus II ini sudah ada revisi maka kekurangan-kekurangan yang terjadi pada siklus I menurut guru mitra sudah diminimalkan.

\section{f. Refleksi}

Berdasarkan hasil dari observasi, pengisian angket, dan wawancara dengan siswa mapupun dengan guru mitra, ternyata sudah ada perbaikan minat belajar. Ini terlihat pada pada tiap pertemuan siklus I maupun siklus II selalu ada kenaikan minat belajar siswa. Dari pengamatan guru maupun guru mitra pun jelas terlihat bahwa motivasi belajar siswa terhadap matematika selalu bertambah. Siswa yang biasanya bicara sendiri sudah bisa diam, siswa yang tadinya kesulitan mengerjakan soal ternyata berani berani bertanya kepada guru.

Tetapi masih ada sedikit kendala dalam proses pembelajaran berbantuan komputer program MS Power ini yaitu karena keterbatasan guru maka proses pembelajaran hanya sebatas pemberian animasi, gambar pada tiap slidenya dan hyperlink. Untuk hal-hal yang lebih canggih guru masih harus lebih banyak belajar lagi. Tetapi hal ini tidak menjadikannya pesimis, karena proses pembelajaran berbantuan komputer program MS Power Point ini masih bersifat percobaan dan memang belum ada satu guru matematika pun yang memulainya. Walapun demikian ternyata proses pembelajaran berbantuan komputer program MS Power Point dapat meningkatkan minat belajar matematika siswa. 


\section{B. Pembahasan}

Setelah selesai pelaksanaan proses pembelajarn berbantuan komputer pada siklus I dan siklus II selesai, maka berikutnya adalah dilakukan pembahasan hasil tindakan yang telah dilakukan. Pada proses pembahasan ini akan dibahas perbandingan hasil angket pada pra penelitian, akhir siklus I dan akhir siklus II, serta perbandingan hasil observasi pada pra penelitian, siklus I dan siklus II.

Tabel 9. Perbandingan hasil angket pra penelitian, akhir siklus I dan akhir siklus II

\begin{tabular}{|c|c|c|c|c|}
\hline NO & ASPEK YANG DIAMATI & PRA PNELTN & SIKLUS I & SIKLUS II \\
\hline 1 & Belajar matematika menyenangkan. & $71,09 \%$ & $72,66 \%$ & $85,94 \%$ \\
\hline 2 & Saya tertarik untuk belajar matematika. & $65,63 \%$ & $60,64 \%$ & $79,69 \%$ \\
\hline 3 & Saya tidak ngantuk menerima penjelasan guru. & $65,63 \%$ & $56,25 \%$ & $80,47 \%$ \\
\hline 4 & Saya mudah mengerjakan soal matematika. & $60,94 \%$ & $78,13 \%$ & $81,25 \%$ \\
\hline 5 & Saya berani mengerjakan soal di papan tulis. & $49,22 \%$ & $51,56 \%$ & $72,66 \%$ \\
\hline 6 & Apabila belum jelas saya berani bertanya kepada & $62,50 \%$ & $64,84 \%$ & $68,75 \%$ \\
\hline 7 & $\begin{array}{l}\text { Saya penasaran dengan pelajaran matematika dan } \\
\text { ingin belajar lebih baik. }\end{array}$ & $70,31 \%$ & $5 \%$ & 75 \\
\hline 8 & Nilai ulangan matematika saya baik. & $63,28 \%$ & $70,31 \%$ & $77,34 \%$ \\
\hline 9 & $\begin{array}{l}\text { Saya bisa menyelesaikan sendiri soal yang diberikan } \\
\text { oleh guru. }\end{array}$ & $20,32 \%$ & $67,19 \%$ & $74,22 \%$ \\
\hline 10 & Saya aktif selama proses pembelajaran matematika & $63,20 \%$ & $73,44 \%$ & $77,34 \%$ \\
\hline 11 & Belajar metematika terasa tidak monoton. & $60,94 \%$ & $67,19 \%$ & $68,75 \%$ \\
\hline 12 & Saya tertantang untuk belajar matematika. & $55,47 \%$ & $59,38 \%$ & $58,59 \%$ \\
\hline 13 & $\begin{array}{l}\text { Selama guru mengajar saya tidak bicara sendiri } \\
\text { dengan teman. }\end{array}$ & $57,81 \%$ & $65,63 \%$ & $78,13 \%$ \\
\hline 14 & Saya memperhatikan penjelasan guru. & $72,66 \%$ & $83,59 \%$ & $81,25 \%$ \\
\hline 15 & $\begin{array}{l}\text { Dalam pembahasan soalsaya berusahamembantu } \\
\text { guru untuk menyelesaikannnya. }\end{array}$ & $71,88 \%$ & $77,34 \%$ & $76,56 \%$ \\
\hline 16 & Saya tidak takut dengan matematika. & $68,75 \%$ & $75,78 \%$ & $73,44 \%$ \\
\hline 17 & Saya mau mengerjakan tugas yang diberikan oleh & $76,56 \%$ & $77,34 \%$ & $82,81 \%$ \\
\hline 18 & Saya memiliki jadwal rutin untuk belajar & $71,09 \%$ & $75,78 \%$ & $82,03 \%$ \\
\hline 19 & Saya bersemangat belajar matematika & $55,47 \%$ & $74,22 \%$ & $81,25 \%$ \\
\hline 20 & Saya rajin belajar matematika & $59,38 \%$ & $64,06 \%$ & $81,25 \%$ \\
\hline
\end{tabular}

Berdasarkan Tabel 9 hasil angket respon siswa terhadap minat belajar matematika sebelum tindakan didapatkan rata-rata $62,17 \%$ ( sedang ). Hal ini menunjukkan bahwa belum ada motivasi yang tinggi terhadap pembelajaran matematika. Dibuktikan bahwa minat belajar siswa selama sebelum menggunakan media pembelajaran berbantuan komputer dengan peogram Power Point belum maksimal yaitu masih banyak siswa kurang perhatian terhadap matematika, terutama dalam hal menyelesaikan soal matematika. Banyak siswa yang masih bertanya pada bebesapa temannya yang lebih pandai. Siswa masih belum yakin dan percaya dengan apa yang dikerjakaannya dan masih kesulitan mengerjakan soal yang diberikan oleh guru. Selain dalam hal mengerjakan soal, ada juga presentase respon siswa yang masih rendah yaitu dalam hal keberanian mengerjakan soal di papan tulis. Hasil angket pra penelitian, akhir siklus I dan skhir siklus II dapat dilihat pada Gambar 1. 
Desimal, 2 (3), 2019 - 228

Yuliar Astuti Dewi

ASPEK YANG
$80,00 \%$
$70,00 \%$
$60,00 \%$
$50,00 \%$
PRESENTASE
$40,00 \%$
$30,00 \%$
$20,00 \%$
$10,006 / 0$
$0,00 \%$

PRA PNLT

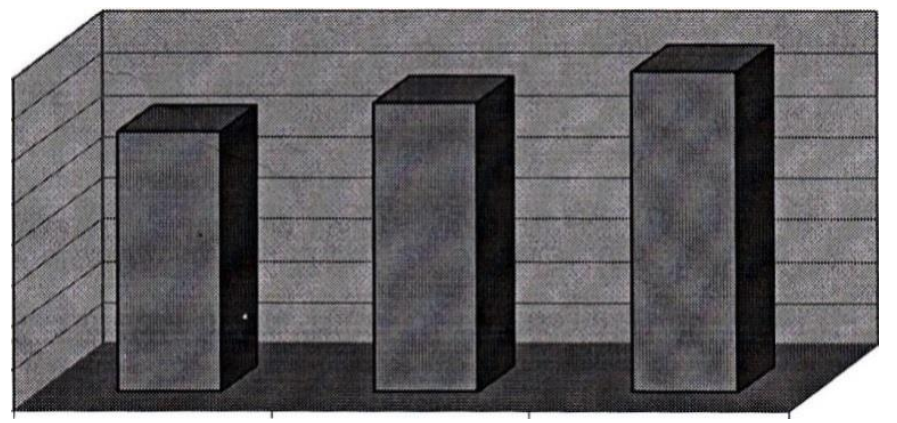

SIKLUS I SIKLUS II

Gambar 1. Perbandingan hasil angket pra penelitian, siklus I dan siklus II.

Pembelajaran matematika selama ini hanya monoton padahal untuk pelajaran matematika dibutuhkan langkah-langkah yang inovatif untuk menambah semangat belajar siswa. Hasil rata-rata angket siklus I didapatkan 69,40\% ( sedang). Walaupun kualifikasi masih sama dengan hasil seelum tindakan tetapi rata-rata sudah mengalami kenaikan sebesar 7,23\%. Jika dilihat dari besarnya kenaikan, yang hanya 7,23\% memang kelihatan kecil dan kurang signifikan. Tetapi hal tersebut bukan merupakan suatu tindakan yang sia-sia. Jika dilihat per butir angket hampir semuanya mengalami kenaikan minat belajar sehingga dapat disimpulkan bahwa sebelum tindakan dan setelah tindakan pada siklus I mengalami kenaikan minat belajar. Proses pembelajarn berbantuan computer program Power Point dapat meningkatkan minat belajar matematika pada siklus I ini. Untuk hasil angket respon siswa terhadap minat belajar matematika setelah tindakan siklus II didapatkan rata- rata 76,88 \% ( tinggi ), berarti dibanding siklus I ada kenaikan sebesar 7,48\% \%. Dari kategori sedang menjadi kategori tinggi. Penambahan minat belajar ini dikarenakan sudah ada langkah yang inovatif yang dilaksanakan oleh guru salah satunya adalah proses pembelajaran dilakukan dengan bantuan komputer program Ms Power Point. Ternyata tindakan ini mendapat respon positif dari sebagian besar siswa, siswa merasa lebih bersemangat dalam belajar matematika. Selama di kelas susasana pembelajaran lebih segar dan tidak monoton. Dengan adanya presetasi pembelajaran program Ms Power Point materi pelajaran disampaikan dengan slide demi slide serta setiap slide diberi tambahan animasi dan gambar-gambar siswa menjadi lebih bergairah dalam menerima pelajaran. Berikut ini adalah diagram hasil angket sebelum dan sesudah tindakan.

Hasil observasi dari pra penelitian, siklus I dan siklus II didapatkan rata-rata yang tampak pada Tabel 10 . 
Desimal, 2 (3), 2019 - 229

Yuliar Astuti Dewi

Tabel 10. Rata-rata basil observasi pada pra penelitian, siklus I dan siklus II

\begin{tabular}{|c|c|c|c|c|}
\hline \multirow[b]{2}{*}{ NO } & \multirow[b]{2}{*}{ ASPEK YANG DIAMATI ( $\mathrm{K}$ ) } & \multicolumn{3}{|c|}{ JUMLAH SISWA ( \% ) } \\
\hline & & $\begin{array}{c}\text { Pra } \\
\text { Penelitian }\end{array}$ & Siklus I & Siklus II \\
\hline 1 & Apabila belum jelas siswa mau mengajukan pertanyaan. & $0 \%$ & $9,38 \%$ & $14,58 \%$ \\
\hline 2 & Dapat menjawab pertanyaan yang diajukan oleh guru. & $6,25 \%$ & $12,50 \%$ & $57,29 \%$ \\
\hline 3 & Siswa dapat membantu mengerjakan contoh soal & $31,25 \%$ & $44,79 \%$ & $68,75 \%$ \\
\hline 4 & Mau berperan aktif selama KBM berlangsung. & $62,50 \%$ & $67,71 \%$ & $89,58 \%$ \\
\hline 5 & Tidak bicara sendiri selama KBM & $62,50 \%$ & $72,92 \%$ & $90,63 \%$ \\
\hline 6 & Mau mengerjakan soal di buku masing-masing. & $75 \%$ & $78,13 \%$ & $100 \%$ \\
\hline 7 & Mau mengerjakan soal di papan tulis. & $0 \%$ & $6,25 \%$ & $10,42 \%$ \\
\hline 8 & Mau mencatat keterangan tambahan. & $50 \%$ & $85,42 \%$ & $92,71 \%$ \\
\hline 9 & Berhasil mengerjakan soal latihan secara individu. & $50 \%$ & $82,30 \%$ & $97,92 \%$ \\
\hline 10 & Dapat menyimpulkan materi pelajaran & $46,88 \%$ & $64,59 \%$ & $79,17 \%$ \\
\hline
\end{tabular}

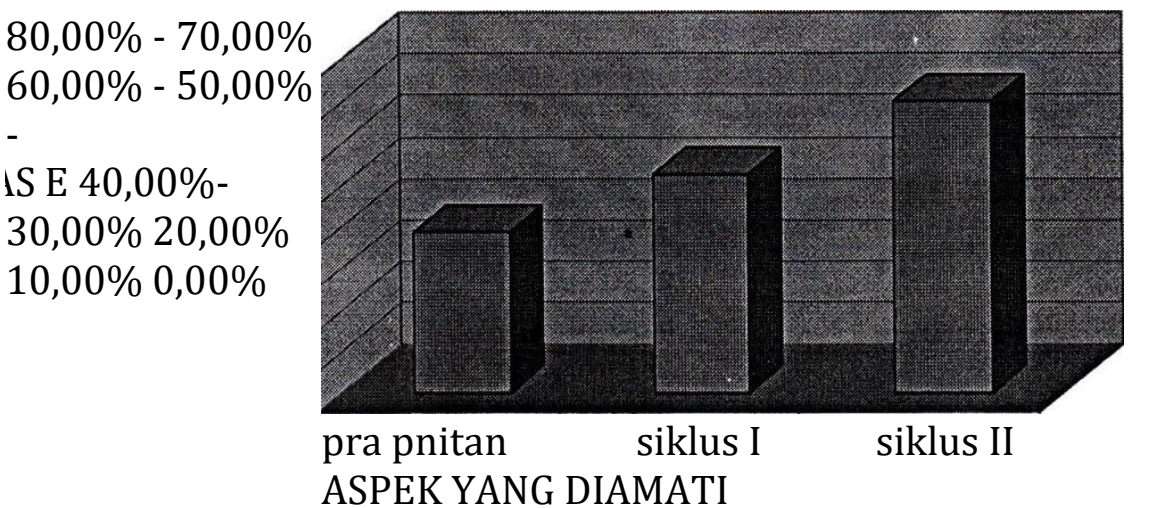

Gambar 2. Hasil observasi minat belajar siswa pra penelitian, siklus I dan siklus II

Dari rata-rata hasil observasi pra penelitian adalah 38,44 \% dan siklus I sebesar $52,40 \%$ berarti ada kenaikan sebesar 13,96\%. Untuk hasil observasi akhir siklus I ke akhir siklus Ilmenunjukkan ada kenaikan minat belajar terutama selama proses pembelajaran sebesar $17,71 \%$. Jika dilihat dari pra penelitian ke akshir siklus II terjasi kenaikan minat belajar sebesar $31,67 \%$. Kenaikan minat siswa terhadap pembelajaran matematika dari siklus I ke siklus II yang paling tinggi persentasenya adalah pada aspek pengamatan menjawab pertanyaan yang diajukan oleh guru. Pada kegiatan ini terjadi kenaikan sebesar $44,79 \%$. Selama proses pembelajaran memang terlihat bahwa siswa di kelas sangat memperhatikan penjelasan guru. Dengan tayangan presentasi yang penuh warna warni, adanya animasi dan gambargambar menjadikan siswa berminat untuk memperhatikannya. Karena siswa perhatian dengan apa yang sudah dijelaskan oleh guru menjadikan siswa lebih banyak menyerap materi yang diajarkan. Dengan demikian setiapguru mengajukan pertanyaan kepada siswa maka sebagian besar siswa dapat menjawabnya. Sedangkan pada aspek pengamatan yang paling sedikit kenaikan psersentasinya adalah pada siswa yang mau dengan sukarela mengerjakan soal di papan tulis. Disini hanya terjadi kenaikan sebesar 4,17\%. Dari hasil pengamatan masih banyak siswa yang takut akan pekerjaannya. Mereka belum yakin dengan hasil pekerjaannya apakah sudah benar atau belum, sehinggga meraka belum berani mengerjakan di papan tulis. 
Sampai akhir siklus II peneliti belum punya strategi yang jitu bagaimana cara memberi semangat kepada siswa sehingga mereka tidak takut salah. Untuk pengamatan yang lainnya terjadi keniakan persentase sekitar 5,2 \% sampai 17,71\%. Walaupun rata-rata kenaikan minat belajar selama proses pembelajaran pada siklus I dan siklus II ini tidak begitu tinggi tetapi hal ini sudah menunjukkan bahwa proses pembelajaran dengan bantuan komputer program MS Power secara keseluruhan sudah bisa meningkatkan minat belajar siswa.

Bagaimana minat belajar matematika dengan bantuan komputer program MS' Power Point ini dapat naik, ini dikarenakan selama proses pembelajaran telah terjadi perubahan, semangat dari sebelum sampai setelah tindakan. Semangat itu berupa minat belajar siswa terhadap matematika. Proses pembelajaran dengan bantuan komputer program MS Power Point yaitu dengan cara menjelaskan materi pelajaran dengan cara menulis di papan tulis kemudian siswa mencatatnya tetapi disini siswa cukup mendengarkan penjelasan guru, siswa hanya mencatat ha-hal yang dirasa perlu saja karena diakhir pelajaran siswa sudah mendapatkan handout dari guru. Demikian juga penjelasan yang dilengkapi dengan media pembelajaran dengan bantuan komputer program MS Power ini banyak ditambah dengan animasi, gambar-gambar pada setiap slidenya dan dilengkapi pula dengan fasilitas hyperlink dalam setiap soal pilihan ganda menjadikan siswa lebih tertarik untuk belajar matematika.

Dari hasil wawancara dengan siswa mapupun guru didapatkan hasil yang sama bahwa pelajaran dengan bantuan komputer merupakan langkah yang lebih maju dibanding sebelumnya. Siswa menjadi tidak ngantuk, lebih memperhatikan penjelasan guru dan frekuensi siswa yang sering bicara sendiri sudah jauh berkurang. Matematika yang selama ini banyak dianggap siswa merupakan pelajaran yang menakutkan ternyata oleh sebagian besar siswa sudah tidak menakutkan lagi.

\section{SIMPULAN DAN SARAN}

Berdasarkan hasil penelitian dapat ditarik kesimpulan bahwa, hasil rata-rata angket minat belajar sebelum tindakan adalah 62,17\%, setelah siklus I adalah $69,70 \%$ dan setelah siklus II adalah $76,88 \%$ (tinggi), hal ini menunjukan bahwa ada kenaikan minat belajar dari pra penelitian ke siklus I 7,53\% dan dari siklus I ke siklus II sebesar 7,18\%. Untuk rata rata hasil observasi minat belajar pra penelitian adalah $38,44 \%$ pada siklus I adalah 52,40\% dan siklus II adalah 70,11\%. Dari pra penelitian ke siklus I ada kenaikan sebesar 13,96\%, dari siklus I ke siklus II naik 17,71\%. Secara keseluruhan dari pra penelitian sampai akhir penelitian ada kenaikan sebesar 31,67\%. Hal tersebut menunjukan bahwa dengan menggunakan media pembelajaran berbantuan komputer program MS Power Point siswa menjadi lebih bersemangat dan berminat untuk belajar matematika.

Berdasarkan kesimpulan tersebut, penulis menyarankan untuk penelitian selanjutnya agar dapat melakukan penelitian dengan kajian yang lebih luas dibandingkan dengan penelitian ini, serta untuk guru matematika agar dalam proses pembelajaran dapat menggunakan media pembelajaran berbantuan komputer program MS Power point.

\section{DAFTAR PUSTAKA}

Afandi, A. (2017). Media ICT pembelajaran matematika menggunakan power point interaktif dan iSpring Presenter. Abdimas: Jurnal Terapan, 2(0), 1-8.

Fitri, H., \& Wardi, Y. (2026). Pengaruh Model Pembelajaran Type Two Stay Two Stray dan Minat Belajar terhadap Hasil Belajar Ekonomi pada Siswa 
kelas X SMA Dian Andalas Padang. Jurnal Ilmiah Mahasiswa (JIM) Pendidikan Fisika, 1(4).

Ghofuri, A. M., Sanusi, \& Krisdiana, I. (2014). Efektivitas Pembelajaran Berbasis Multimedia Menggunakan Power Point Dengan Pendekatan Pembelajaran Berbasis Masalah (Problem Based Learning) Ditinjau Dari Motivasi Belajar Siswa. JIPM: Jurnal Ilmiah Pendidikan Matematika, 3(1), 1-7.

Ginting, S. M., \& Hermansyah, A. (2012). Penerapan Model Pembelajaran Somatis Auditori dan Intelektual (SAVI) Berbantuan Media komputer Untuk Meningkatkan Kualitas Pembelajaran Kimia Fisika II. Jurnal Exacta, 10(1), 98-105.

Harsyad, F., Afif, A., \& Abrar, A. I. P. (2016). Studi Komparasi Penggunaan Ice Breaking Dan Brain Gym Terhadap Minat Belajar Matematika Siswa Kelas VII SMP Negeri 21 Makassar. Jurnal Matematika Dan Pembelajaran, 4(2), 184-197.

Heruman. (2007). Model Pembelajaran Matematika di Sekolah Dasar. Bandung: PT Remaja Rosdakarya.

Oktaria, D., Zulkardi, \& Somakim. (2013). Pengembangan Website Bahan Ajar Turunan Untuk Meningkatkan Minat Belajar Peserta Didik. Jurnal Kependidikan, 43(2), 107-115.

Siagian, R.E.F. (2015). Pengaruh Minat dan Kebiasaan Belajar Siswa Terrhadap Prestasi Belajar Matematika. Formatif: Jurnal Ilmiah Pendidikan MIPA, 2(2).

Suratno. (2013). Pengaruh Penerapan Metode STAD Terhadap Hasil Belajar Ekonomi Ditinjau Dari Minat Siswa Di SMA N 10 Batanghari. Jurnal Pendidikan Ekonomi Dinamika Pendidikan, 8(2), 111-122.

Wahidi, A. (2017). Learning Quantum Chemical Model with Learning Media Concept Map and Power Point Viewed from Memory and Creativity
Skills Students. Journal of Education, Teaching and Learning, 2(1), 100104.

Wibowo, A. (2017). Pengaruh Pendekatan Matematika Realistik dan Saintifik Terhadap Prestasi Belajar, Kemampuan Penalaran Matematis dan Minat Belajar. Jurnal Riset Penelitian Matematika, 4(1), 1-10\. 